\title{
Additive Manufacturing: Currently a Disruptive Supply Chain Innovation?
}

\author{
Per Engelseth \\ Tromsø Shcool of Business and Economics \\ Narvik Campus, UiT, The Arctic University of Norway, 8514 Narvik Norway, \\ E-mail: pen008@uit.no (Corresponding Author)
}

\author{
Maryam Salman \\ Department of International Business \\ Norwegian University of Science and Technology, NTNU Ålesund, 6025 Ålesund, Norway \\ E-mail: maryam.salman56@gmail.com \\ Waqas Mushtaq \\ Department of International Business \\ Norwegian University of Science and Technology, NTNU Ålesund, 6025 Ålesund, Norway \\ E-mail: waqas_mushtaq@yahoo.com \\ Fahad Awaleh \\ Kristiania University College, Oslo Norway, 0153 Oslo Norway, \\ E-mail: Fahad.Awaleh@kristiania.no \\ Remiguisz Kozlowski \\ Center of Security Technologies in Logistics, Faculty of Management \\ University of Łódź, 90 - 237 Łódź, Poland, \\ E-mail; remigiusz.kozlowski@wz.uni.lodz.pl \\ Richard Glavee-Geo \\ Department of International Business \\ Norwegian University of Science and Technology, NTNU Ålesund, 6025 Ålesund, Norway \\ E-mail: rigl@ntnu.no
}

\begin{abstract}
Directs attention to additive manufacturing in a supply chain context. Analysis questions the degree it currently is a disruptive innovation. A case study consisting of interviews with 15 companies, including observations of some of these companies, providing a varied set of subcases. The research describes individual companies' histories of using 3D printing tools, its current use and future prospects, as perceived by various informants. In the supply chain, additive manufacturing moves production closer to the product user, albeit currently on a small scale. Some firms are already specializing in providing additive manufacturing as a service. Networking and sourcing emerge as increasingly important issues to govern the development and use of additive manufacturing technology in the value chain of each studied company. Findings reveal how additive manufacturing at current is in its infancy and has limited impact on the networked production structure: it has not yet reached the stage of being a disruptive innovation. Investigation also reveals perceptions on how additive manufacturing in the near future
\end{abstract}

may change the logistics flow structure in global supply chains, then becoming a disruptive innovation.

Keywords: technology management, additive manufacturing, disruptive innovation, $3 D$ printing, integration; supply chain change; network structure.

\section{INTRODUCTION}

Additive manufacturing is in industry expressed with 3D (three dimensional) printing tools. These relatively small machines work slowly but produce exactly the product that it was programmed to create. This digital technology is well adapted to creating one-of kind products, up to now, mainly in plastic. Intuitively, a main advantage of this technology is to bring production design and the actual production closer to the customer. It also should enable faster delivery of such products. This is clearly a new way of producing, up to now, relative small-sized products. Given the increasing use of this technology, it is pertinent to ask whether additive 
manufacturing a disruptive innovation? This study does not dwell into the specificities and use of this technology. This paper addresses, instead, the impact of additive manufacturing on the supply chain structure and the logistics process therein thus enabling this technology thereby to create customer value. In this industrial network structure, the role of customer is relative. Customers are organised in tiers in a chain-like pattern. These intermediaries, with roles as both suppliers and customers, are more or less integrated in coordinating logistical operations, as described through Alderson's (1965) transvection model. Ultimately, following Alderson's (1965) view, the end user appraises the total value of the logistical service provided by this conglomerate of mutually interdependent suppliers. This approach to supply also bridges understanding of how to integrate a marketing with a logistics perspective of supply (Engelseth and Felzensztein 2012). In the network structure, a relatively stable inter-organisational setting, additive manufacturingalso known as 3D printing or desktop fabricationrepresents resource use associated with a particular form of new technology. Perceptions of value of this technology are considered. This encompasses considerations of both value for supplier as well as value for customer.

Additive manufacturing represents new technology. Technology use is shown to emerge incrementally through use in a supply chain (Engelseth et al. 2020). This implies emergent consideration regarding innovative use in industry, including how goods are supplied using this technology. The following research question guided inquiry providing empirical grounds for this paper from a separate unpublished case study:

RQ1: What characterises additive manufacturing as a technology used by a firm?

RQ2: What are the uses of additive manufacturing in the supply chain structure and its impact thereafter?

RQ3: What value does additive manufacturing add to the firm?

Additive manufacturing is a novelty in its supplyrelated use. Regarding additive manufacturing as an innovation, it is valid to consider the degree to which increasing use radically changes supply chain structure and processes. In this paper we discuss based on the empirical evidence from the mentioned case study how disruptive is this innovation within the context of the supply chain? To determine this, we consider the following research issues for this paper: (1) the impact of additive manufacturing on network structure context and the logistics this context supports and (2) the extent to which additive manufacturing is a disruptive innovation. This paper provides a detailed description of 15 companies' perceptions of current and future use of additive manufacturing. This paper prioritizes detailed presentation of empirical findings: a large empirical section is sandwiched between a brief frame of reference and a commentary based on the findings in a brief conclusion. Readers are therefore motivated to create their own conceptions in addition to those briefly proposed in the paper, which mainly provide the reader 15 slices of life regarding 3D printing use in industry, 14 of which are cases from Norway. This poses a methodological limitation. With the empirical grounds of this study embedded in a wilfully light conceptual frame of reference, this provides direction for further research on the use of additive manufacturing in supply chains.

\section{LITERATURE-BASED FRAME OF REFERENCE}

Bower and Christensen (1995) conceptualize 'disruptive innovation' as innovation that creates a new market and organizational network, radically changing customer needs and displacing established market-leading firms, products and alliances. If an innovation is disruptive, it means that the networked market agents will need to rethink how they produce and exchange (do business) in the value creating networks of industrial relationships facilitating production and transaction exchanges. Old agents may die and new ones may become important. Previously weak agents may become more powerful, or vice versa. Old processes of exchange and production may also change. It is therefore important to analyse to the degree to which additive manufacturing, an increasingly common production and exchange, can be characterized as a disruptive innovation.

This study concerns physical distribution (as opposed to services). In such production transforming the time place and form features of goods takes place in a network structure. This structure may be characterized by interdependencies, integration and interaction (Janusz et al. 2018). Interdependency characterises reasoning to relate, integration the strength and duration of the relationship, and interaction the actual work going on in these economic relationships. Value characterises the purpose of production ultimately perceived by the end-user regarding time, place and form features (Alderson 1965). The local versus the global supply chain structure is an increasingly important subject of investigation (Laplume, Petersen, \& Pearce, 2016; Li, Jia, Cheng, \& Hu, 2017; Rogers, Baricz, \& Pawar, 2016; Wagner \& Walton, 2016). The literature discusses how proximity to customers facilitates co-creation (Rayna \& Striukova, 2015; Rayna, Striukova, \& Darlington, 2015). This also implies the consideration of new business models, focusing on proximity in business relationships as a key factor associated with organizing supply (Pisano, Pironti, \& Rieple, 2015). Anderson, Havila, Andersen and Halinen (1998) regard firms as actors that own different resources, perform exchange activities and have relationships. Networks can therefore be described as structures composed of exchange relationships between actors who own and use different resources. These are not stable networks. They are continuously changing due to time-specific interaction in existing relationships. It has been argued that supply chain networking dynamics can be understood based on the interplay between the positions and roles of the actors (i.e. the firms). The increasing use of additive manufacturing implies a change in network structure by moving the site of some of the production - mainly of components of finished products - from large-scale factories to small units often found at the location of the industrial producer.

Following Anderson et al. (1998), the network position in a supply chain depicts the situation of the actors in a given network structure, embracing the expected activities known as 'taken on activities', while the role describes what the actors intend to do, how they construct meaning in a situation and how they bring changes to it. The existence of these two dimensions, position and role, can be found in any business 
network. The dynamics in any network are unique in comparison to those in other networks. The primary determinant of actors' activities, and therefore of the network dynamics, is attributed to the ability of the actors to interpret changes and create meaning for their own and other actors' network positions and roles (Anderson et al., 1998).Changes in value networks can therefore be explained by the empirically detected activities an actor performs, given its position within a less dynamic value network structure.

The role and position of actors and their interactions in a supply chain structure may lead to innovations through the creation and transfer of shared knowledge. This has been studied by Guercini and Runfola (2015), who considered that the innovation role of actors can be defined in terms of their learning and teaching processes, as well as the internal and external relationships that they maintain. The basic assumption in this study is that the actors carry out and leverage a complex set of roles that define their unique profiles. The innovation push of the actor is determined by the set of roles, which in turn depends on the nature of interactions with other actors, both external and internal to the system. Additive manufacturing currently represents an emerging example of the measurable impact of technology change on the supply chain network.

In the case of additive manufacturing, innovation is clearly technology driven. Öberg, Shams and Asnafi (2017) state that most studies on additive manufacturing concern technology. Hoover and Lee (2015) state that additive manufacturing can be considered disruptive as it changes industry settings, but Sandström (2016) disagrees with this based on a detailed case study in the hearing aid industry, which considered the $3 \mathrm{D}$ printing of hearing aid shells. Sandström (2016) points out that the increased use of 3D printing in the hearing aid production industry was economically driven. As the technology became cheaper to implement and more efficient to use, a previously artisanbased profession was eliminated. The reasoning for the industry to take up the use of $3 \mathrm{D}$ printing was mainly as a competitive necessity. The industry structure, however, remained largely the same, although the making of the hearing aid shells-products designed for an individual user's ear-was digitalized. Sandström (2016) therefore concludes that the implementation of additive manufacturing mainly involved a competence-destroying process of innovation rather than a disruptive innovation. This indicates that additive manufacturing may have the same consequences as modernistic mass production: the reduction or even elimination of handicraft skills in the production of goods. This also implies an impact on the institutional layer of production and raises another question regarding the degree to which innovation is a threat to how goods are currently distributed. Is then this potential or actual shift of production to small-scale facilities closer to the customer a disruptive innovation? This implies considering what industry now is doing to use this technology.

\section{METHOD}

Informants were found through suggestions given within a rather transparent regional industrial network using snowball sampling. Many informants suggested other informants. At the onset of the study, the aim was to secure about ten informants. Surprisingly, at the end, the snowballing became quite rapid, and it was easy to complete 15 interviews. Some informants, such as those from a global logistics company, were encountered at an international purchasing conference. The 15 industry experts were therefore interviewed using a standardized guided interview, which is appropriate for obtaining information on the same and comparable topics in different companies. Finding the informants was done through combined judgment and convenience sampling. To perform interviews the team applied their network to find out if there were companies, predominately in Norway, that presently used 3-D printing. The study is not limited to Norwegian companies, and it is not the aim to limit this study to Norway, rather, through a set of somewhat coincidental interviews provide information on various tropics that are prudent regarding the current use of 3-D printers in society. Some interviews were also supplemented with observations through plant tours when the interviewers on some occasions visited the production location. Based on the information gathered in our interviews, secondary data and supplementary observations, we sought to shed light on the actual or potential impact of additive manufacturing on the supply chain structure.

The 15 informants were interviewed through a combination of face-to-face and telephone interviews. For informants located geographically close to the researcher's place of work, personal interviews were attempted, including observations of the production facilities and secondary data research. In each company one interview was conducted with what the company indicated was a focal person involved in the question of 3-D printing use. This is a limitation since it only provides a single perspective. For our initial-stage research on the current status quo of additive manufacturing, this was considered adequate. This study consists accordingly of 15 small subcases, one based on each interview. It functions as a case study since it provides a study of additive manufacturing use in the different company contexts based on interviews, observations and the use of secondary data. To study the additive manufacturing process technology in further detail, 3D printing facilities were observed. Multiple steps are required for 3D printing, including the production of the 3D model of a part/product using CAD software, usually provided by the manufacturer of the $3 \mathrm{D}$ printer, and transfer of the file to a computer that controls the 3D printer, the printer setup, the layer-by-layer build-up, the removal of the part/product from the 3D printer and post-processing steps including a wash with chemicals and cleaning. Table 1 provides a list of the companies interviewed.

Out of the 30 companies contacted, only 15 companies were interviewed. Several of the informants opted to keep their names undisclosed in case of publication. Interviews were based on set of fixed questions about how potential or actual use of additive manufacturing (in practice, 3D printing) affects each company's supply chain network, how it is different from industry to industry, and to what extent it can affect a company's supply chain network structure. We also considered the key elements for a company to implement additive manufacturing in production and the key elements that prevent a company from implementing additive manufacturing in production and limit the use of 3D printing technology for prototypes only. 
Table 1. List of companies interviewed

\begin{tabular}{|c|c|c|c|}
\hline Companies & Date \& Time & Interview mode & Industry \\
\hline$A$ & $\begin{array}{l}24.04 .2018 \\
14: 30 \text { CEST }\end{array}$ & Skype & Maritime \\
\hline B & $\begin{array}{l}\text { 02.05.2018 } \\
\text { 17:36 CEST }\end{array}$ & Email & $\begin{array}{l}\text { Aerospace \& } \\
\text { Defence }\end{array}$ \\
\hline C & $\begin{array}{l}\text { 13.04.2018 } \\
\text { 12:00 CEST, } \\
\text { 19.04.2018 } \\
\text { 13:00 CEST }\end{array}$ & $\begin{array}{l}\text { Site visit, Face- } \\
\text { to-face }\end{array}$ & Furniture \\
\hline D & $\begin{array}{l}19.04 .2018 \\
14: 00 \text { CEST }\end{array}$ & $\begin{array}{l}\text { Site visit, Face- } \\
\text { to-face }\end{array}$ & $\begin{array}{l}\text { Industrial plastic } \\
\text { products }\end{array}$ \\
\hline$E$ & $\begin{array}{l}\text { 17.04.2018 } \\
\text { 12:00 CEST }\end{array}$ & $\begin{array}{l}\text { Site visit, Face- } \\
\text { to-face }\end{array}$ & $\begin{array}{l}\text { Children's } \\
\text { furniture and } \\
\text { Equipment }\end{array}$ \\
\hline $\mathrm{F}$ & $\begin{array}{l}\text { 23.04.2018 } \\
\text { 15:00 CEST }\end{array}$ & $\begin{array}{l}\text { Site visit, Face- } \\
\text { to-face }\end{array}$ & Air compressors \\
\hline G & $\begin{array}{l}\text { 02.05.2018 } \\
\text { 12:00 CEST }\end{array}$ & $\begin{array}{l}\text { Skype, } \\
\text { Telephone, } \\
\text { Email }\end{array}$ & $\begin{array}{l}\text { Industrial products, } \\
\text { oil \& gas/geology, } \\
\text { medical, } \\
\text { packaging }\end{array}$ \\
\hline $\mathrm{H}$ & $\begin{array}{l}27.04 .2018 \\
12: 00 \text { CEST }\end{array}$ & Skype & $\begin{array}{l}\text { Industrial plastic } \\
\text { products }\end{array}$ \\
\hline I & $\begin{array}{l}30.04 .2018 \\
10: 00 \text { CEST }\end{array}$ & Skype & $\begin{array}{l}\text { Industrial plastic } \\
\text { products }\end{array}$ \\
\hline $\mathrm{J}$ & $\begin{array}{l}\text { 30.04.2018 } \\
\text { 15:00 CEST }\end{array}$ & Skype & $\begin{array}{l}\text { Water and Gas } \\
\text { fittings }\end{array}$ \\
\hline K & $\begin{array}{l}\text { 03.05.2018 } \\
\text { 10:00 CEST }\end{array}$ & Skype & $\begin{array}{l}\text { Aerospace-grade } \\
\text { titanium } \\
\text { components }\end{array}$ \\
\hline L & $\begin{array}{l}\text { 30.04.3018 } \\
\text { 13:00 CEST }\end{array}$ & Skype & Metal parts \\
\hline M & $\begin{array}{l}\text { 18.04.2018 } \\
\text { 13:00 CEST }\end{array}$ & Telephone & $\begin{array}{l}\text { Supply chain, } \\
\text { Logistics }\end{array}$ \\
\hline $\mathrm{N}$ & $\begin{array}{l}\text { 03.05.2018 } \\
\text { 13:00 CEST }\end{array}$ & Skype & $\begin{array}{l}\text { Professional } \\
\text { lighting solutions }\end{array}$ \\
\hline 0 & $\begin{array}{l}\text { 02.05.2018 } \\
\text { 10:00 CEST }\end{array}$ & Skype & Mechatronics \\
\hline
\end{tabular}

Each interview lasted for almost an hour and had a clear intersubjective character, meaning that each interview was framed in reciprocal interdependence. The interviews were all learning processes, and new questions could easily be generated as a result of the preceding responses to follow up on new and unexpected lines of inquiry. Figure 1 provides an overview of the research process.

\section{COMPANY CASE NARRATIVES}

\subsection{Company $A$}

The main business activity of Company A consists of systems for dynamic positioning and navigation, marine automation, handling systems, safety management, cargo handling, subsea survey, construction, marine training, satellite positioning and autonomous solutions. The company carries out in-house production of sonars and has sub-contractors delivering parts, but mostly finishes the product in-house. Recently, it started 3D printing, primarily for prototyping, but about a year ago, the company also introduced 3D printing for in-house tooling. Usually it does not print products to be sold, but it recently launched a product that it is going to sell. Benefits of additive manufacturing include saved cost and time, creating a high turnaround speed allowing the company designer to create tooling overnight. Ordering such a product from a machine shop usually takes three weeks. The company has three ultimate gear printers that are running almost continuously. For a designer, the biggest benefit is that they can create parts with 3D printing that they simply cannot make using traditional machining or moulding, or that would be incredibly expensive. The informant still regards 3D printing as still immature, as both printers and materials are "new". The components the company is currently printing are printed from supplier designs using selective laser sintering (SLS) nylon printing, which produces relatively highcomplexity, low-volume parts. This does not have such a significant impact on the supply chain structure, because the tools are very low volume. The company is currently building a production unit with five automaker printers, which are controlled by robot and will make single-use moulds 24/7. It also hopes to have access to a metal printer not too far in the future, and the company will have several different printers, both for production and for prototyping.

Table 2. Interview guide

\begin{tabular}{|c|c|}
\hline $\mathrm{S} / \mathrm{N}$ & Interview Guide \\
\hline 1 & $\begin{array}{l}\text { Describe the current supply chain structure (suppliers and } \\
\text { customers)? }\end{array}$ \\
\hline 2 & $\begin{array}{l}\text { Describe the current use of 3-D printing in your production. } \\
\text { Benefits \& Challenges? }\end{array}$ \\
\hline 3 & $\begin{array}{l}\text { How has the use of 3-D printing changed the structure of the } \\
\text { supply chain? }\end{array}$ \\
\hline 4 & Why did the firm choose to implement 3-D printing? \\
\hline 5 & What are the realized benefits from the use of 3-D printing? \\
\hline 6 & How do you envision the future use of 3-D printing? \\
\hline
\end{tabular}

\subsection{Company $B$}

Company B produces systems for command and control (land, air and sea-based), weapons guidance and surveillance (maritime and land-based), communications solutions (predominantly land-based) and missiles (anti-ship and naval strike missiles). The company started 3D printing to increase the speed of prototyping. Currently, it is using a ProJet 3500 3D printer to produce plastic parts for simple functional tests during the design process. This gives it the opportunity to quickly try out many different design ideas, as it does not have to wait for parts to be delivered from an external supplier. The company also uses a $3 \mathrm{D}$ printer to make some special tools. The benefit of this is the ability to make complex, specialized tools quickly and at a low cost. The downside of using the current 3D printer to make tooling is the limited strength of the plastic material, and the inability to make assembly fixtures where electrical conductivity is required. Supplier and customer relationships and transactions have essentially continued as before, although $3 \mathrm{D}$ printing has given the company a chance to shorten the product design cycle, and hopefully come out with a better final design. 


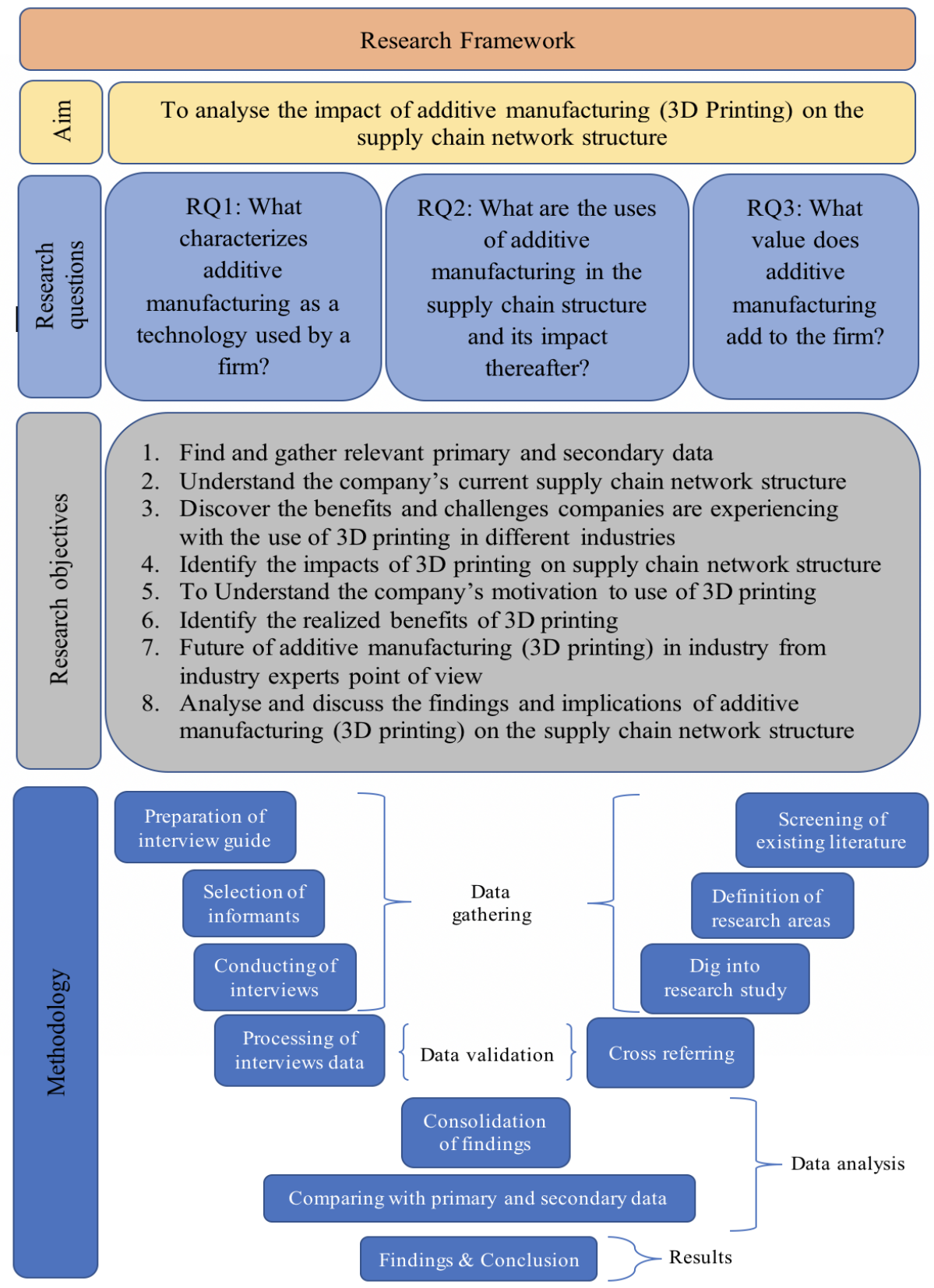

Figure 1 The research process

The realized benefits are that it is much easier to get a good impression of a design's proportions with a scale model compared to just looking at it on a screen; to do test assemblies to uncover design faults before ordering expensive hardware; to make low-cost specialized tools for specific assembly operations; and to replace these tools quickly if needed. Additive manufacturing, the informant believes, will widen the design possibilities for the structural complexity of parts. Designing additional features into a part can eliminate assembly steps and reduce time for final assembly. When 3D printing in metal becomes readily available, the informant believes it will be possible to make functional components in-house in a shorter time than ordering from an external supplier, but the technology for metal 3D printing is not yet mature. Traditional machining is still, in most cases, a cheaper and faster solution. For this type of additive manufacturing to be cost effective, one needs parts designed from the bottom up.

\subsection{Company $C$}

Company $\mathrm{C}$ is a large furniture manufacturer with a series of international brand names and currently uses 3D printing in product development for testing prototypes. Because the company is involved in the mass production of furniture, it is not possible to produce this with a $3 \mathrm{D}$ printer. A benefit of 3D printing is the customization of the product for a customer. The informant points out that there are many challenges in 3D printing, including mass production and the quality and finishing of the $3 \mathrm{D}$ printed products. The cost of 
the industrial 3D printer, as well as the cost per unit because of low production volume, could also be a challenge. Making parts moulds with the help of 3D printing technology, this could be done in a couple of days by the company itself. However, the 3D printed product quality is not currently good enough. The company therefore chooses to use 3D printing technology for product development. It is easy to design, test and redesign (if required) overnight before sending a product for production. In the near future, the informant expects that the technology will be developed that would allow the possibility of multiple 3D printing - that is, metal, plastic, aluminium, cutting, sewing and knitting all together. More distantly, with one big 3D printer, the company could produce a complete chair and, in that case, the supply chain network will change completely. This will also present the possibility to do in house all those activities that are currently outsourced by the company, but only when the volume is high enough. There is continuous improvement in the technology and, if it achieves the level necessary to produce large volumes with good quality, then this could be an easy way to produce very complex products in an effective and profitable way.

\subsection{Company $D$}

This rather small company produces technical plastic injection moulding parts. These are thermoplastic parts for industry and product suppliers. It typically produces for its customers, who control the products' production facilities on a contractual order basis. In addition to the actual production, the company also offers services within the regular manufacture of the product. The current supply chain structure of this company is simple. Interestingly, some of the customers are also its suppliers, as they use the company's production services to get their product produced on time in a sufficiently large volume. Currently, the use of $3 \mathrm{D}$ printing is part of product development and not in production for commercial use. The company prints prototypes in the development process to visualize the product and for testing. The development time goes down when using $3 \mathrm{D}$ printed prototypes. The company has also tested out 3D prints of injection moulding tools, and 3D printing works suitably with products of simple geometry in small volumes. Customization or redesign of a product is simple and less time-consuming using 3D printing. The development of raw material in $3 \mathrm{D}$ printing means that the company can do more tests on the applicable product, which reduces the development time. In some cases, the $3 \mathrm{D}$ printed products can be used as a finished product, but this is still a very limited use. The quality of the raw material to test the strength and functionality of the product has proved an obstacle in using 3D printing. With the current technology, it is also not possible for the company to produce large volumes. This, however, is normally required by most of the customers, within a demanded time expressed often as "as short as possible". Moreover, the cost of industrial 3D printers is high and the number of products produced per day is low in comparison to the current injection moulding system. The motivation to use $3 \mathrm{D}$ printing was to learn about the technology and to use it for the betterment of the service, as it significantly enhances product development, redesign, customization and testing. The benefit of 3D printing is that product redesign is simple using CAD software: the prototype can be produced overnight for testing, whereas in traditional manufacturing it is time consuming to get the injection moulding tool that is adapted to the product being produced.

\subsection{Company $E$}

Company E focuses exclusively on premium children's furniture and equipment within the highchair, baby carrier, stroller, home textiles and nursery market segments. It offers worldwide distribution of premium children's furniture and equipment. The company outsourced all its manufacturing many years ago, meaning the business concept is mainly product design, marketing and maintaining the supply chain. The company has been using 3D printing for prototyping for the last fifteen years, but it does not use this technology for production, as it does not produce the products. Hypothetically, it would use 3D printing in production because the benefit of using 3D would be to customize parts - such as through the addition of the customer name or colour providing added value. The customer could order from a website and it could be produced in the warehouse. The challenges of 3D printing include the slow speed of production and the quality of the product. This is important because the company markets premium products. Because it deals with children's products, every single product needs to be thoroughly tested and approved before it can be delivered to the customer. At the moment, the use of $3 \mathrm{D}$ printing in prototyping is very helpful for product development. However, if the company chose to implement it in production, then the incentive for the company would be the opportunity to customize the product to add more value for the customer. This would also be the realized benefit of using $3 \mathrm{D}$ printing in production.

\subsection{Company $F$}

Company $\mathrm{F}$ is one of the world leading starting air compressors producers. This type of machine part is often used in shipbuilding. It does not matter whether the customer compressor is new or 30 years old: the company still offers $24 / 7$ service for spare parts to all its customers. The company's current supply chain is large and multifaceted. It has over 200 suppliers and customers worldwide; it has suppliers for various product types, such as iron castings, valves, electric and control components, sensors for compressors, and so forth. Some of its suppliers produce their own designs, and this leads to partnerships with many other suppliers. The company has been using 3D printing for the past two years, primarily for modelling, prototyping, marketing, proposals and testing. Currently 3D printing is not being used in production. The current manufacturing process is based on robotic computer numerical control (CNC) machines. However, if the company were to use 3D printing in production, it believes that the benefit would include quick access to casted parts, so long as the materials and quality were comparable to the existing products. However, as of today, this is a very expensive solution for production. The company has some high-volume products and parts, but most are standard products, although a few are engineering modified and developed according to customer needs. If high-volume iron casting 3D printers existed, they would be helpful to print spare parts, so the company would not need an extremely expensive $\mathrm{CNC}$ machine. One 
challenge in the future would be to protect its own genuine spare parts. As to customer benefit, the company believes that it could be possible to license the designs and print parts closer to the customers anywhere in the world, thus reducing the lead-time in the future. This could result in a global network of intellectual property, where a customer pays a fee to print the parts owned by the originator of the product. This would, however, create the challenge of protecting intellectual property countries, such as China and Russia, where piracy is more common. The company is still learning about this technology and how to use it to create new ideas and bring improvements throughout the value chain. This would help workers to adopt the new technology in the future. The company started with rapid prototyping and its production engineers continually experiment with 3D printing on a routine basis, and this has helped familiarize them with the technology and creates new opportunities to create and test new ideas. The informant perceived that 3D printing would create quick access to parts, which could be printed overnight and tested. Redesign is easy for personnel using 3D printing, which is particularly impressive for modelling and marketing purposes. The company also believes that, as the technology develops, it will be able to produce many products in-house at a high quality, such as gaskets, which are a very simple to produce with a $3 \mathrm{D}$ printer.

\subsection{Company $G$}

Company $\mathrm{G}$ has always regarded itself as being at the forefront of innovation in manufacturing. Over the past 40 years, it has developed, produced and delivered customized industrial products and technical solutions for customers both in Norway and abroad, providing competitive advantage and profitability. The company is dependent on purchasing a range of different parts. It always has power, gas and filters in stock. Upon receiving an order, the production planner creates the time schedule for production, which is confirmed with the customer. When parts are produced, they are delivered to the customers. Sometimes the machining has to be done before delivery. The company has several hundred suppliers, and it has at least two or three customers for $3 \mathrm{D}$ printing almost every month. The company needed a 3D printer for a project in 2011 because creating different parts was not then possible through traditional machining. It therefore continues to adopt this technology and to grow with the development of 3D printing, using the process to produce parts for customers in both metal and plastic that cannot be created through alternative methods. $3 \mathrm{D}$ printing is considered an expensive production method compared to machining. For this technology to be effective in use, it must produce special designs that are not available elsewhere.

The main benefit the company has found from 3D printing and machining is that it provides good service to customers and gives the company the opportunity to make special parts that are not possible by machining. Delivery is also faster using 3D printing (1-2 weeks) than for traditional machining (5-6 weeks). The informant believes that the 3D printed product is regarding quality equivalent to the product produced by machining. There will also be more benefits when the people know more about this technology: at present, there are still very few people who know about it, particularly for printing metal because there are few companies that sell this type of technology. The company has devoted much time to informing industry players about $3 \mathrm{D}$ printing for producing parts that are not possible through machining. The company believes, however, that 3D printing will become better known in the engineering industry and the price for the printing will then drop. There will also be faster machines in the future, so the company believes that in the next five to ten years very different technology will be available that can produce faster at a low cost.

\subsection{Company $\mathrm{H}$}

Company $\mathrm{H}$ supplies plastic parts to product manufacturers. It delivers a wide range of plastic parts to many different industries with diverse demands and requirements. The company has three or four main customers and several smaller ones. The biggest customer at the moment is a supplier of equipment for fish farming, whose main products are circular rings placed in the sea for aquaculture production. The company makes the brackets and walkways (excluding the pipes) in different sizes. This company has been using 3D printing in prototyping for ten years. When it has a new product, the personnel always discuss or design new plastic parts with their customers: they are experts in injection moulding, and they need to see if the design is good to produce and is ready to mould. If some part needs to be modified, it is very expensive and time consuming to make changes to the existing mould. It is therefore very important that the need for adjustment or changes is eliminated before the company starts making the mould. This is the one big advantage of prototypes: there is less risk of mistakes when prototypes are developed. The company injects moulding parts, carrying out design and product development for prospective customers. The personnel then design and print prototypes for the customer's approval. The designers use CAD with simulation to determine how things can be assembled and fitted, so a physical sample is required for checking. Scaled models are created for large customers. The fish farm parts are very large, and it is not possible to 3D print such large models to show the customers, so small scale models are currently printed to present to customers. Most of the parts weigh around $10 \mathrm{~kg}$ or more. Compared to injection moulding, 3D printing is perceived as being competitive for small parts and for very low volumes, and it is also very useful in areas where there are specific problems with traditional methods.

The company previously used external suppliers for 3D printed prototypes and models, but now it can print in-house to show new products to prospective customers. This means that it is easier for customers to choose this company as a supplier because the company can efficiently develop new parts: it prints a sample overnight rather than ordering from a supplier, so 3D printing provides an advantage for in-house samples. The technology helps eliminate possible mistakes that could be very costly if personnel had to fix them in the finished mould. The company believes that $3 \mathrm{D}$ printing may compete with other production techniques and the company's vision for 3D printing is that it will be used increasingly for producing small parts. 


\subsection{Company I}

Company I is a provider of innovative and competitive solutions for prototyping and plastic production. It delivers different types of plastic parts using injection moulding, usually as a subcontractor for other companies. The company workers guide the customer from the early stage of product development to the initial product, and uses prototyping to help customers get the right product. The company purchased and started using a 3D printer in 2005 for prototype development for its customers, and a few years later, it started the patented process called 'duo combe'. If a product is complex, then the mould becomes very expensive; to reduce the cost, especially for large-volume products, the company has developed a technology so the moulding cost is kept low for low-volume products. This allows an initial test of the products in the market. The company then started a project that has been very successful, called AddForm, where it simply prints different types of mould with different types of material. With the help of suppliers, the company combines different types of material and technology in one mould, which can be useful to produce specific products from injection moulding. There are three main areas where the company is using 3D printing, including AddForm. The primary use is still in its research and development phase. The stability of material properties represents a major challenge. However, development is proceeding rapidly with the cooperation of an applied research organization for product testing and development. The second area is the use of $3 \mathrm{D}$ printing for prototypes, and the third area of use is for the printing of fixtures, logos, text and other parts for atomization in serial production. Since the company started the AddForm project, its 3D printer has become obsolete, although personnel use it for making the parts. There are many different technologies with superior properties, so the company now purchases printed parts - that were previously produced in-house - from external suppliers. The company collaborates well with some of these companies, which are partners in the AddForm project. To be on a par with the latest in technology, the company may purchase a new printer to ensure quality and efficiency. The informant believes that, eventually, many of the parts that are now produced by injection moulding in the factory will be produced directly by $3 \mathrm{D}$ printing in the future. The use of $3 \mathrm{D}$ printing will make products customized to a much higher degree than today - for all customers if they want it - rather than mass producing and making the same products for everyone. In terms of reducing the lead-time with 3D printing, it is a developing rather than a transporting model. Transporting moulds occupies a very small part of the company's time. It takes about five to eight weeks to make traditional moulds; if the company prints a prototype, it is usually produced within a week. The company produces 10,000 or more units a year, and for some products, there are around 1,000 to 2,000 units a year. If the mould cost is split over the number of products in a year or two, then the product becomes very expensive, so $3 \mathrm{D}$ printing is mainly a production supplement. As the 3D printing technology develops and improves, there will be a significant change in the production network, as the company will start printing the moulds itself, faster, but the company believes that it will take some years for 3D printing to have an impact on how goods are produced and supplied.

\subsection{Company J}

Company $\mathrm{J}$ develops and supplies couplings and related products to the Scandinavian and European water and gas distribution industry. The company's main products are composite and brass couplings, ductile iron, threaded pipefittings and tapping saddles. The company uses 3D printing to check the assembly. Prototypes are checked according to the standards of material properties and to foresee the final products. To help producers and consumers discuss the features and the strengths and weaknesses of the product outcome, 3D printing is used to showcase the product. Currently, the company is challenged by the continuous upgrading of the quality of its products in terms of durability and order volume. The challenge in the volume of products means the company has to make injectionmoulding tools, which represents a major investment. To secure product profitability, it is vital to produce these on a larger scale. The available 3D printing technology is still very limited. The company plans to use $3 \mathrm{D}$ printing in production based on the material and printing technology. The maker of the printer also provides the materials, becoming a new supplier in the supply chain. The company prints using EOS materials: EOS is the global technology leader for industrial 3D printing of metals and polymers. Polyamide powder is a good material, but it does not give the desired strength, and the 3D printing quality is currently not available for the company's application.

\subsection{Company $K$}

Company $\mathrm{K}$ was founded by entrepreneurs, scientists and engineers with a vision to pioneer the next industrial revolution by developing and commercializing significantly less expensive aerospace-grade titanium components. It collaborates with several organizations who believe in and invest in its project and help the company essentially change manufacturing forever, launching the new industrial age. Within the company, 3D printing is perceived to reduce the lead time significantly and use cheaper raw materials, because the parts do not have to be machined from massive blocks of titanium. The 3D printing-based process saves material, time and money. Keeping production costs and lead-time at a minimal level remains a challenge for the company. The cost of the $3 \mathrm{D}$ printer machine is also a challenge. The machine can produce 10 to 20 metric tonnes of aerospace-grade titanium parts per year so that the company meets the demands of its clients. The company is founded on additive manufacturing technology — it is, in fact, the company's fundamental business vision. There have been a few changes in the manufacturing process, but not in the structure of the supply chain. The benefits of using 3D printing are perceived to be greater efficiency and cost effectiveness. The company opened a factory in the USA with more machines for potential clients in order to have a faster delivery system, and this has the advantage of proximity to customers with the use of $3 \mathrm{D}$ printing. The company sees great potential in the use of $3 \mathrm{D}$ printing. The management is certain that additive manufacturing will be the world's leading manufacturing process for titanium parts and regards additive manufacturing as the future of this industry. Reduction of cost and lead-time can only be achieved in additive manufacturing. Waste cannot be used in any other parts because the capabilities of the material have 
to be changed: there is a need to melt it down again to create a new block of titanium.

\subsection{Company $L$}

Company $\mathrm{L}$ is the first Norwegian company to implement laser metal deposition technology for additive manufacturing. This technology complements other techniques available in the company's network and completes the capability at today's technological level. The company has had a machine for about a year and delivered the first produced part before Christmas 2017-a satellite component for a space company. The company works only with metal parts and its owners are more or less also its customers. The company is testing different business models that are slightly different from other companies. It is cooperating with one of its important customers on tool repair. The customer sends the company the tool; the company fixes it and rebuilds the surface, and does the finishing so that the customer has a completely refurbished part. The end customers are also the suppliers, but there is also a supplier of metal powder used for refurbishing the products. The company finds it cheaper to refurbish the product through additive manufacturing. Its main focus is on refurbishing the parts rather than making a new part. According to the management, 3D printing is of sufficient quality for commercial purposes. The company uses only super alloy for additive manufacturing. Investment in the 3D printer machine is costly. The 3D printing machine is part of the company's production facility and reduces the lead-time. The company observed that the traditional method of refurbishment for some components takes several weeks: its focus is to produce it within a week and 3D printing technology speeds up the refurbishment. Normally, the tool refurbishment cycle takes four to five weeks or longer, but with $3 \mathrm{D}$ printing, this is accomplished in the company's own facility within two days at a much higher quality. Prices are higher because the process is so expensive, but it saves a lot of time. For other customers, like the offshore petroleum industry, the company has a huge lead time on the refurbishment of components, and for a new product, the lead time is long - around five to twelve months. Through $3 \mathrm{D}$ printing technology, the company can produce in a much faster, more efficient and effective way. The informant worked within additive manufacturing for a few years before this company was founded as a researcher at a university in Norway, and noticed that, in industry, some people did not really have sufficient knowledge or skills to operate and to use this technology. The company is an early adopter of additive manufacturing technology worldwide, and has found that it is a good time to introduce this technology in production. The company tries to focus on products that can be used where the alternative cost of components is very high, such as with maintenance components, and it tries to find where it can add more value with its technology. To compete effectively in this market, the company developed this form of digital manufacturing. The company believes that many companies fear that 3D printing will take away their markets and change the way they manufacture parts. For this company, it is just another tool in a toolbox with new limitations and opportunities. It does not believe that 3D printing will replace traditional manufacturing processes, such as injection moulding: it will perhaps replace it in some aspects, but not in general terms.

\subsection{Company $M$}

Company $\mathrm{M}$ is one of the world's leading providers of supply chain solutions. The company combines its core products - air freight, ocean freight and logistics and manufacturing to deliver globally integrated, tailor-made end-to-end solutions for twelve core industries, drawing on in-depth industry knowledge and customized IT systems. It manages the needs of its customers' supply chains, no matter how demanding these supply chains might be. The company operates a global network with some 500 offices in around 70 countries, and it works with partner companies in another 100 countries. The company started a logistics manufacturing service, having realized that many of the customers' goods - particularly spare parts - are sitting in warehouses. Additive manufacturing was explored as a potential solution to this problem. Rather than storing these spare parts for years and not needing them, can a company print them when the need arises? Also, rather than shipping these goods or using air freight, can companies just manufacture parts where the demand is? The kinds of product they store in the warehouses vary: they could be from any sector, such as automotive, perishables, chemicals or fashion. The company has no fixed set of customers. It started exploring doing this production itself, but realized that it was not as straightforward as it looks. There is not just one printer that prints everything, but rather there is a range of technologies and a range of materials. They began by partnering with Shapeways, an online platform for 3D printing that has been using different additive manufacturing technologies for years. The company also bought a Projet 3500 HDMax 3D printer by 3D Systems. Ultimately, however, this company is a LSP so it is never going to be as good as a manufacturing company that has been doing this for years. The company provides the services of a supply chain, so it is a service company. It moves products around the world for customers, linking suppliers and manufacturers where there is demand. It would be best for this logistics service provider to develop a logistics solution. The solution it developed looks at customers' supply chains and identifies - from hundreds and thousands of products - those products that are suitable for 3D printing. Such produces are slow moving, low in volume, high in value, very complicated and hard to source. The company changed its business model and developed the supply chain solution rather than an engineering solution. Although it considers engineering principles, it focuses on the supply chain, which is where its core strengths are. This is also beneficial in terms of what value-added service the company is willing to bring to the market. If customization is required, then the company can bring that to the market exclusively on demand. An example would be if a customer wants a phone tomorrow in a specific colour. The product is assembled at the company's warehouses. It will be able to supply the parts through additive manufacturing according to customer specifications in a short time from warehouses close to where the customer is located. The customer no longer needs mass produced things, but rather things that are specific, customized and personalized. Customers are also not willing to wait for weeks, but want the products delivered within a day or two. 
The company provides business to a competitor who is willing to provide the product faster. This is the process that has led the firm to additive manufacturing and most of its customers are focused on the manufacturing benefits of $3 \mathrm{D}$ printing: it provides the design complexity, with personalization and customization, without additional cost.

\subsection{Company $N$}

Company $\mathrm{N}$ is a manufacturer that develops, manufactures and distributes professional lighting solutions worldwide. It has a prototyping facility workshop in its factory that includes a $3 \mathrm{D}$ printing facility. It uses $3 \mathrm{D}$ printing for limited serial production. Currently, the company has a project that needs only 200 pieces per year of a little plastic part; it is not effective to build a moulding tool for this part, so the company decided to order it from a subsupplier in Norway as a prototype $3 \mathrm{D}$ printed product. It also uses $3 \mathrm{D}$ printing to build production equipment in the factory. The company is very price-focused and has no products for commercial purposes. Normally, the luminaire it is selling has a minimum of five to ten thousand products per year, so it is not cost-effective for the company to have them 3D printed. Based on the company's experience, one of the challenges in the use of 3D printing is the price per part. Production time is another challenge. For high volume products, it is more effective to use injection moulded products. The cost of the machine is also considered a challenge, but it depends on the product material being used. For SLS material, the machine is affordable, but for metal parts, the machine is much more expensive. The company places high value on speed as being essential to the development process. It is also important to the management to get better products for product developers and 3D printing provides more flexibility for testing things. If someone has an idea, they can build it up using a CAD system and, with $3 \mathrm{D}$ printing, it is possible to build a physical model and test it, which is easier than the practice of 20 years ago. The company can test several solutions to get better products, which is a big benefit of a 3D printer. The company has been using the machine in-house for three years now, though the technology has been around for more than ten years already. The company had the opportunity to make vacuum-moulded silicon parts, but this would be time consuming. Ordering prototypes from sub-suppliers is another option for the company. It used to order prototypes from another supplier: if there were parts which it could not print, such as fused deposition modelling (FDM) technology, or very small and thin parts, it usually ordered these parts from the subsuppliers. However, using the $3 \mathrm{D}$ printer, everything is done in-house by the company, and the company chose to implement 3D printing to assist in the development process, to test ideas and concepts and to speed up the development process. Personnel can do more experiments with 3D printing: they can test parts in real time. This is the firm's avenue to promote innovation and the development of products and services. More than anything else, 3D printing has resulted in a speedy process: it speeds up the development time, it is flexible and it is good for testing and innovation. The company has significant experience with 3D printing technology. It has enjoyed the many benefits of 3D printing not available with traditional processes of product development and showcasing. The suitability of 3D printing is dependent upon the kind of industry using it; the medical industry, for example, has expensive supplies and machines, and 3D printing could be a suitable solution because would allow patient-personalized custom products. Metal printing is a great potential for this company. There are other issues, however, such as certification. Still, there are many possibilities, because moulded parts-especially in combination with moulding manufacturing in China - are so cost effective in mass produced manufacturing compared to $3 \mathrm{D}$ printing. The cost reductions associated with $3 \mathrm{D}$ printing are predominately connected to product development and small-scale manufacturing.

\subsection{Company $O$}

Company $\mathrm{O}$ produces cables, connectors and moulds for electronic equipment in plastics. It offers a full range of products within the field of mechatronics. The company has departments for mechanical and electromechanical development and production. Its customers are from a wide range of fields, including oil and gas, ocean space, naval defence, fisheries, fish farming and mining. The company is continually investing in skilled employees and modern technology. In addition to being a 'one stop shop' and providing customer service, the company has recently developed new products and technologies for the subsea and fishery industries. It is the preferred development partner for many of the major technology companies in Norway, as it provides added value and is known for its flexibility. The company acquires a 3D model from customers and its personnel prints the model in different materials from plastic to metal. The company carries out some engineering, identifying which printer is the best for the particular job before delivering the product back to the customer. The company has two 3D printers and has partnered with other firms, working with their employees and collaborating on their printing needs, allowing the firm access to four different types of industrial $3 \mathrm{D}$ printer. The biggest printer it has at the moment has a volume of $250 \times 250 \times 300 \mathrm{~mm}$, which covers most of the jobs related to the company's products. The current use of 3D printing is in production, as most of the company's products are made using industrial 3D printing. The company delivers finished products, but 3D printing is also used for prototyping, from ideas to finished parts with good quality. The company also prints metal and titanium, so the company believes there are many opportunities, but customers are not always aware of these products and services. The company is working to build awareness, so that people will start thinking that $3 \mathrm{D}$ printing can be used to produce finished products. It is a challenge to find a product that can be produced through $3 \mathrm{D}$ printing to sell. The ability to print large quantities depends on the size of the product: if it is a small part, a whole chamber of the $3 \mathrm{D}$ printer can be filled with the products. Because the product will print overnight, it takes a shorter time to bring to market. Another challenge of the $3 \mathrm{D}$ printer is using it to design a product that has to be developed in a different way. The $3 \mathrm{D}$ printing process adds material, rather than subtracting it. In the traditional manufacturing process, which some customers demand, products are designed for machining. Such products are not cheap to produce with the $3 \mathrm{D}$ printer, and specialized knowledge is needed to design the product such that it can be produced from a $3 \mathrm{D}$ printer. 
Printers are costly. For this reason, the company is not able to buy all types of printer and must work together with other companies. The company believes that the printer can be located anywhere in the world because it does not have a traditional assembly chain. It is also easy to move the printer from one place to another, which is not the case with the traditional manufacturing setup. On the customer side, reducing the lead-time is a big change: a product can now be delivered in hours rather than weeks or months. This new process also provides the opportunity to produce products that were not previously produced using traditional machining. The company can experiment and innovate more with $3 \mathrm{D}$ printing technology. It can print, test and redesign if needed. This new technology also helps the company to find new customers in a new sector and has gained many customers this way. The company uses $3 \mathrm{D}$ printing to be competitive in the market with the digitalization of manufacturing technology. The company believes that 3D printing will become more advanced, more people will know about it and it will become more widely used. The company believes that 3D printing will not take over traditional machining, but will gain a bigger share in production. The current major challenge is that people are not aware of industrial 3D printers. People are starting to learn about 3D printing technology in school now: it has already entered into the school system, and in the future, the new generation will start thinking about designing products using 3D printers.

Table 3 Summary of findings

\begin{tabular}{|c|c|c|c|c|c|c|}
\hline ID & Use motivation & Current Use & Benefits & Challenges & Effect on SCN & Future Use \\
\hline$A$ & $\begin{array}{l}\text { New possibilities } \\
\text { and techniques. } \\
\text { Time and } \\
\text { complexity of the } \\
\text { parts. }\end{array}$ & $\begin{array}{l}\text { Prototyping only, in- } \\
\text { house tooling. Low } \\
\text { volume, highly } \\
\text { complex products. }\end{array}$ & $\begin{array}{l}\text { Reduced cost and lead } \\
\text { time, high turnaround } \\
\text { speed, creation of complex } \\
\text { parts. }\end{array}$ & $\begin{array}{l}\text { Re-learn to design, } \\
\text { quality vs accuracy } \\
\text { and tolerance. }\end{array}$ & $\begin{array}{l}\text { No impact because of in- } \\
\text { housing. }\end{array}$ & $\begin{array}{l}\text { Access to metal printer, } \\
\text { start production. }\end{array}$ \\
\hline B & $\begin{array}{l}\text { As a rapid } \\
\text { prototyping tool. }\end{array}$ & $\begin{array}{l}\text { Plastic parts for } \\
\text { simple functional tests } \\
\text { in design process. }\end{array}$ & $\begin{array}{l}\text { Production of complex, } \\
\text { specialized tools fast at low } \\
\text { cost. }\end{array}$ & $\begin{array}{l}\text { Limited strength, } \\
\text { limited use due to } \\
\text { electrical conductivity. }\end{array}$ & $\begin{array}{l}\text { No impact but it has } \\
\text { shorten-ed design cycle. }\end{array}$ & $\begin{array}{l}\text { Widen the design } \\
\text { possibilities. Will start } \\
\text { metal printing. }\end{array}$ \\
\hline C & $\begin{array}{l}\text { Product } \\
\text { development, } \\
\text { production of fast } \\
\text { changing parts in- } \\
\text { house. } \\
\end{array}$ & $\begin{array}{l}\text { Product development } \\
\text { and testing of } \\
\text { prototypes. }\end{array}$ & $\begin{array}{l}\text { Ease of design and testing, } \\
\text { customization, saves time } \\
\text { in product development. }\end{array}$ & $\begin{array}{l}\text { Mass production, } \\
\text { quality and finishing of } \\
\text { the product, high cost. }\end{array}$ & $\begin{array}{l}\text { No impact since it is not } \\
\text { used in product-ion. }\end{array}$ & $\begin{array}{l}\text { Use of multiple materials in } \\
\text { 3D printer, production of } \\
\text { large volume in good } \\
\text { quality. }\end{array}$ \\
\hline $\bar{D}$ & $\begin{array}{l}\text { To improve the } \\
\text { services offered. }\end{array}$ & Prototyping & $\begin{array}{l}\text { Reduced time, } \\
\text { customization, ease of } \\
\text { redesign. }\end{array}$ & $\begin{array}{l}\text { Quality of raw } \\
\text { materials, strength } \\
\text { and functionality of } \\
\text { the product. }\end{array}$ & $\begin{array}{l}\text { No impact till now as it is } \\
\text { not used in production. }\end{array}$ & $\begin{array}{l}\text { Technology to faster } \\
\text { produce quality products in } \\
\text { large volume. }\end{array}$ \\
\hline $\mathrm{E}$ & $\begin{array}{l}\text { Product develop- } \\
\text { ment and } \\
\text { customization. }\end{array}$ & Prototyping & $\begin{array}{l}\text { Customization, reduced } \\
\text { lead time. }\end{array}$ & $\begin{array}{l}\text { Low speed, technical } \\
\text { quality, large volume. }\end{array}$ & No changes yet. & $\begin{array}{l}\text { Will improve quality and } \\
\text { surface strength. Increase } \\
\text { in volume. }\end{array}$ \\
\hline$F$ & $\begin{array}{l}\text { Learn the techno- } \\
\text { logy and bring new } \\
\text { ideas and improve- } \\
\text { ment in value chain. }\end{array}$ & $\begin{array}{l}\text { Modelling, } \\
\text { prototyping, } \\
\text { marketing, testing and } \\
\text { proposals. }\end{array}$ & $\begin{array}{l}\text { Quick access to casted } \\
\text { parts, easy to re-design, } \\
\text { can print over-night and test } \\
\text { them. }\end{array}$ & $\begin{array}{l}\text { Expensive, will create } \\
\text { copyright issues in } \\
\text { future. }\end{array}$ & $\begin{array}{l}\text { No particular change in } \\
\text { supply chain network. }\end{array}$ & $\begin{array}{l}\text { More in-house production } \\
\text { with high quality, will } \\
\text { reduce the number of } \\
\text { suppliers. }\end{array}$ \\
\hline G & $\begin{array}{l}\text { For a project whose } \\
\text { parts could not be } \\
\text { made by machining. }\end{array}$ & $\begin{array}{l}\text { Production of parts in } \\
\text { metal and plastic. }\end{array}$ & $\begin{array}{l}\text { Quick delivery of parts, } \\
\text { ability to made parts not } \\
\text { possible with machining. }\end{array}$ & $\begin{array}{l}\text { Not well known in the } \\
\text { market yet, few } \\
\text { people have } \\
\text { knowledge of it. }\end{array}$ & $\begin{array}{l}\text { Increase in the number of } \\
\text { suppliers and customers. }\end{array}$ & $\begin{array}{l}\text { Will be more well known, } \\
\text { faster pro-duction at low } \\
\text { cost. }\end{array}$ \\
\hline $\mathrm{H}$ & $\begin{array}{l}\text { For testing samples, } \\
\text { fix possible } \\
\text { mistakes. }\end{array}$ & $\begin{array}{l}\text { Prototyping and } \\
\text { designing. }\end{array}$ & $\begin{array}{l}\text { Reduced risk of modifying } \\
\text { the design, easy to } \\
\text { showcase samples. }\end{array}$ & $\begin{array}{l}\text { Can only print small } \\
\text { scale models, low } \\
\text { volume. }\end{array}$ & $\begin{array}{l}\text { No need of suppliers for } \\
\text { 3D printing, can be done } \\
\text { in-housed. }\end{array}$ & $\begin{array}{l}\text { Will be used for producing } \\
\text { large parts and in high } \\
\text { volume. }\end{array}$ \\
\hline I & $\begin{array}{l}\text { To find weak spots } \\
\text { in product design. }\end{array}$ & $\begin{array}{l}\text { Research and } \\
\text { development, } \\
\text { prototyping, } \\
\text { atomization in serial } \\
\text { production. }\end{array}$ & $\begin{array}{l}\text { Testing at early stage } \\
\text { saves time and cost later in } \\
\text { production, reduced lead } \\
\text { time. }\end{array}$ & $\begin{array}{l}\text { Stability, material } \\
\text { properties, accuracy, } \\
\text { high cost of } \\
\text { production. }\end{array}$ & $\begin{array}{l}\text { No specific change in the } \\
\text { supply chain yet. }\end{array}$ & $\begin{array}{l}\text { More production of } \\
\text { customized parts, may } \\
\text { have an impact on supply } \\
\text { chain in future. }\end{array}$ \\
\hline $\mathrm{J}$ & $\begin{array}{l}\text { For assembly study } \\
\text { with prototypes. }\end{array}$ & $\begin{array}{l}\text { Prototyping for } \\
\text { studying the concepts. }\end{array}$ & $\begin{array}{l}\text { Displaying to customers, } \\
\text { testing samples, flexibility, } \\
\text { short development time. }\end{array}$ & $\begin{array}{l}\text { Better properties with } \\
\text { higher strength. }\end{array}$ & $\begin{array}{l}\text { No impact yet but will add } \\
\text { suppliers when used for } \\
\text { production. }\end{array}$ & $\begin{array}{l}\text { Technology will improve to } \\
\text { produce high quality metal } \\
\text { and plastic parts. }\end{array}$ \\
\hline $\mathrm{K}$ & $\begin{array}{l}\text { To deliver parts with } \\
\text { less lead time. }\end{array}$ & $\begin{array}{l}\text { Produce titanium } \\
\text { parts for aircrafts. }\end{array}$ & $\begin{array}{l}\text { Reduction of lead time and } \\
\text { cost of raw materials, low } \\
\text { waste of materials, saves } \\
\text { time and money. }\end{array}$ & $\begin{array}{l}\text { costs, lead time at } \\
\text { minimal level, quantity } \\
\text { quality of raw material }\end{array}$ & $\begin{array}{l}\text { No change in supply } \\
\text { chain, only changed the } \\
\text { manufacturing process. }\end{array}$ & $\begin{array}{l}\text { Huge potential, will be } \\
\text { world leading } \\
\text { manufacturing process for } \\
\text { titanium parts. }\end{array}$ \\
\hline L & $\begin{array}{l}\text { Opportunity to } \\
\text { deliver parts with } \\
\text { reduced lead-time. }\end{array}$ & $\begin{array}{l}\text { Production of } \\
\text { specialized products. }\end{array}$ & $\begin{array}{l}\text { Reduced lead-time, zero } \\
\text { waste, cheap refurbish- } \\
\text { ment, high qly, saves time. }\end{array}$ & $\begin{array}{l}\text { High cost of the } \\
\text { machine. }\end{array}$ & $\begin{array}{l}\text { No change in supply } \\
\text { chain as the firm is based } \\
\text { on 3D printing. }\end{array}$ & $\begin{array}{l}\text { Huge impact in future, way } \\
\text { to compete with the rest of } \\
\text { the world. }\end{array}$ \\
\hline$M$ & $\begin{array}{l}\text { Customers need } \\
\text { and demands, } \\
\text { reduce wastage. }\end{array}$ & $\begin{array}{l}\text { Production of parts on } \\
\text { customers' demands. }\end{array}$ & $\begin{array}{l}\text { Value-added services, } \\
\text { customization, reduced } \\
\text { lead time. }\end{array}$ & $\begin{array}{l}\text { Technical skills and } \\
\text { knowledge. }\end{array}$ & $\begin{array}{l}\text { Reduce the supply chain } \\
\text { complexity and delay. }\end{array}$ & $\begin{array}{l}\text { Will become affordable and } \\
\text { hence applicable to more } \\
\text { products. }\end{array}$ \\
\hline $\mathrm{N}$ & $\begin{array}{l}\text { For testing different } \\
\text { ideas to speed up } \\
\text { the development }\end{array}$ & Prototyping, & $\begin{array}{l}\text { Flexibility, redesign, and } \\
\text { innovation. }\end{array}$ & $\begin{array}{l}\text { Price per part and the } \\
\text { production time for } \\
\text { high volume products. }\end{array}$ & $\begin{array}{l}\text { No change in supply } \\
\text { chain network. }\end{array}$ & $\begin{array}{l}\text { More production at high } \\
\text { speed and good quality. }\end{array}$ \\
\hline 0 & $\begin{array}{l}\text { To invest in the } \\
\text { future and be } \\
\text { competitive in the } \\
\text { market. }\end{array}$ & $\begin{array}{l}\text { Production and } \\
\text { prototyping in plastic, } \\
\text { metal and titanium. }\end{array}$ & $\begin{array}{l}\text { Reduces lead-time, helps to } \\
\text { innovate, offer huge } \\
\text { flexibility, ability to print } \\
\text { anywhere. }\end{array}$ & $\begin{array}{l}\text { High cost, lack of } \\
\text { knowledge on } \\
\text { customer side. }\end{array}$ & $\begin{array}{l}\text { Shortened time to } \\
\text { market. }\end{array}$ & $\begin{array}{l}\text { Understanding the } \\
\text { technology will increase } \\
\text { production in the industry. }\end{array}$ \\
\hline
\end{tabular}




\section{FINDINGS}

This section provides a comprehensive overview of the findings from the 15 company interviews. Table 3 provides a summary of the empirical results of this qualitative survey. Table 3 presents a simplified overview of current 3-D printer use in each of the companies. Functionality denotes the purpose of the applies technology. The use column indicates the practical sue of this technology and value indicates an interpretation of the impact of this technology use in the overall workings of this company in its market context. The table shows importantly variation is the perceived usefulness in the use of additive manufacturing technology. Table 4 expands on the previous table by providing an overview of the functionality of the technology used, coupled with its value in use for the firm:

Table 4. Applied technology and value in use

\begin{tabular}{|c|l|l|l|}
\hline ID & Functionality & Use & Value* \\
\hline A & Prototyping & in-house tooling & Low \\
\hline B & $\begin{array}{l}\text { Rapid prototyping } \\
\text { tool }\end{array}$ & Testing in design process & Low \\
\hline C & $\begin{array}{l}\text { Product } \\
\text { development }\end{array}$ & Testing of prototypes. & Low \\
\hline D & Prototyping & $\begin{array}{l}\text { Design and testing for } \\
\text { production }\end{array}$ & Low \\
\hline E & $\begin{array}{l}\text { Product } \\
\text { development }\end{array}$ & Prototyping & Low \\
\hline F & Prototyping & Modelling and testing & Low \\
\hline G & $\begin{array}{l}\text { Commercial } \\
\text { production }\end{array}$ & Metal and plastic parts & High \\
\hline H & Prototyping & Designing and samples testing & Low \\
\hline I & $\begin{array}{l}\text { Prototyping } \\
\text { Research and development, } \\
\text { atomization in serial } \\
\text { production. }\end{array}$ & Low \\
\hline J & Prototyping & Sample testing and assembly & Low \\
\hline K & $\begin{array}{l}\text { Commercial } \\
\text { production }\end{array}$ & Titanium parts for aircrafts. & High \\
\hline L & $\begin{array}{l}\text { Commercial } \\
\text { production }\end{array}$ & $\begin{array}{l}\text { Specialized products, } \\
\text { refurbishment }\end{array}$ & High \\
\hline M & $\begin{array}{l}\text { Commercial } \\
\text { production }\end{array}$ & $\begin{array}{l}\text { Customized products, value- } \\
\text { added services }\end{array}$ & High \\
\hline $\mathrm{N}$ & Prototyping & Testing and redesigning & Low \\
\hline O & $\begin{array}{l}\text { Production and } \\
\text { prototyping }\end{array}$ & $\begin{array}{l}\text { Plastic, metal, and titanium } \\
\text { parts }\end{array}$ & High \\
\hline
\end{tabular}

\section{CONCLUDING DISCUSSION}

In the introduction of this paper, we identified the following two areas of research interest: (1) the impact of additive manufacturing on supply chain structure and (2) to the degree to which additive manufacturing is a disruptive innovation. Regarding the first research issue, it is clear that the use of additive manufacturing is primarily limited to prototyping and small-scale commercial production. Additive manufacturing moves production closer to the customer, and this increases the potential for negotiating production and adapting it to user needs. Some firms have specialized in providing additive manufacturing as a service to other manufacturers. This does in such cases change the value network structure, because it implies outsourcing: the inter-firm borderlines as somewhat altered. The specialized service providers, however, often have additive manufacturing as an important part of their production technology. The importance and value of this outsourcing is still limited, but gradually expanding. Many of the firms are manufacturers who have begun using additive manufacturing as an alternative, more efficient supplement to their production. In all cases, this represents a very limited value for the company. The value of additive manufacturing through the use of 3-D printers is mainly associated with one of a kind or small-series production. The use of this form of production also limits the expense associated with waiting. In the case of prototyping, additive manufacturing saves production time. In the case of commercial production, it reduces the need to store in warehouses parts that are seldom needed or, alternatively, to order and wait for them from an external supplier. Use of 3-D printer provides savings in logistics and prototyping costs. This use, however, changes the existent supply chain structure to only a minor degree. The flow of goods is, however, in general, radically changed through the use of 3-D printing since raw material are streamed further downstream for small-scale production. Still, the use of 3-D printing in value networks is limited.

3D printers are now mainly beneficial to production of costly and/or critical products. Technological advances in additive manufacturing may change this. The event of economical mass production using additive manufacturing technology, however uncertain, will clearly disrupt the structure of supply chains. This is associated with the quality of the products made, how fast they are produced and the increasing use of metal 3D printers. It is natural to conclude that there is the potential of technologically improved $3 \mathrm{D}$ printers, together with increased use of this technology. This implies increased need to consider this innovation as disruptive. All the informants state that they expect that additive manufacturing will gradually increase in use. Most of the informants express an understanding that additive manufacturing technology is changing and thus becoming more applicable due to both cost and functionality. This potential increasing use of additive manufacturing also increases the need for raw material supply while reducing the logistics for finished products, which rely on very different types of logistics resources. The impact of especially the change in logistics through using 3-D printing calls for further investigation into the economics of this radical change. Regarding how 3-D printer use economizes supply of the parts this could involve applying analytics including simulation and algorithmic optimization to study processes using additive manufacturing technology. In addition, the case of networking and outsourcing, the role and structure of a supply chain as it changes through increasing use of additive manufacturing should be investigated. A quantitative survey may secure methodological aims of generalization.

\section{REFERENCES}

Alderson, W. (1965). Dynamic marketing behavior. A functionalist theory of marketing, Richard D. Irwin, Homewood, IL.

Anderson, H., Havila, V., Andersen, P., \& Halinen, A. (1998). Position and role: Conceptualizing dynamics in business networks. Scandinavian Journal of Management 14, 167-186. 
Bower, J. B., \& Christensen, C. M. (1995). Disruptive technologies: Catching the wave. Harvard Business Review 73 (1), 43-53.

Guercini, S., \& Runfola, A. (2015). Actors' roles in interaction and innovation in local systems: A conceptual taxonomy. Journal of Business \& Industrial Marketing 30 (3/4), 269-278.

Engelseth, P. and Felzensztein, C. (2012). Intertwining Relationship Marketing with Supply Chain Management through Alderson's Transvection. Journal of Business and Industrial Marketing 27(8), 673-685.

Engelseth, P., Törnroos, J.-A. and Zhang, Y. (2020). Network Coordination of Outsourced Engineering Services: -Towards a Process-Focused View, Journal of Manufacturing Technology Management, in press.

Hoover, S., \& Lee, L. (2015). Democratization and disintermediation: Disruptive technologies and the future of making things. Research Technology Management 58(6), 31-36.

Janusz, A., Bednarek, A., Komarowski, L., Boniecki, P. and Engelseth, P. (2018). Networked Interdependencies and Interaction in a Biotechnology Research Project. IMP Journal 12(3), 460-482.

Laplume, A. O., Petersen, B., \& Pearce, J.M. (2016). Global value chains from a $3 \mathrm{D}$ printing perspective. Journal of International Business Studies 47(5), 595-609.

Li, Y., Jia, G. Z., Cheng, Y., \& Hu, Y. C. (2017). Additive manufacturing technology in spare parts supply chain: A comparative study. International Journal of Production Research, 55(5), 1498-1515.
Öberg, C., Shams, T., \& Asnafi, N. (2017). Additive manufacturing: Current knowledge and missing perspectives. Potsdam, Germany: CINet.

Pisano, P., Pironti, M., \& Rieple, A. (2015). Identify innovative business models: Can innovative business models enable players to react to ongoing or unpredictable trends? Entrepreneurship Research Journal 5(3), 181-199.

Rayna, T. \& Striukova, L. (2015). Open innovation 2.0: Is co-creation the ultimate challenge? International Journal of Technology Management 69 (1),38-53.

Rayna, T., Striukova, L., \& Darlington, J. (2015). Cocreation and user innovation: The role of online $3 \mathrm{D}$ printing platforms. Journal of Engineering and Technology Management 37, 90-102.

Rogers, H., Baricz, N., \& Pawar, K. S. (2016). 3D printing services: Classification, supply chain implications and research agenda. International Journal of Physical Distribution \& Logistics Management 46(10), 886-907.

Sandström, C. G. (2016). The non-disruptive emergence of an ecosystem for $3 \mathrm{D}$ printing: Insights from the hearing aid industry's transition 1989-2008. Technological Forecasting and Social Change 102, 160-168.

Wagner, S. M., \& Walton, R. O. (2016). Additive manufacturing's impact and future in the aviation industry. Production Planning \& Control 27(13),11241130 .

Per Engelseth is full professor in logistics at UiT, The Arctic University of Norway, Narvik Campus. He has received his Dr. Oecon title from BI Norwegian Business School in 2007 on a thesis titled "Using the Package as an Information Resource in the Supply Chain, -A case study of distributing fresh foods to retailers in Norway". Research interests: Case studies, international distribution and goods and services, traceability, engineering management, collaboration, local foods, complexity, networked sustainability and most recently healthcare service logistics. He has supervised data collection, initial analysis and administered this research project.

Maryam Salman was a student at the Norwegian University of Science and Technology Ålesund campus Norway. She has contributed importantly with data collection and to the fundamental analysis of this paper.

Waqas Mushtaq was a student at the Norwegian University of Science and Technology Ålesund campus Norway. He has contributed importantly with data collection and to the fundamental analysis of this paper.

Fahad Awaleh is associate professor in the fields of management strategy and logistics at Kristiania University College Norway. Research interests include strategizing business relationships in industrial networks. He has contributed to analysing and writing up this paper.

Remiguisz Kozlowski is associate professor in technology management and logistics at the Faculty of Management, University of Łódź, Poland. Research interests include using technology to in an innovative manner solve logistics problems in supply chains. Presently he is researching new technology use in healthcare logistics. He has contributed to analysing and writing up this paper.

Richard Glavee-Geo is associate professor in international business at the Norwegian University of Science and Technology Ålesund campus in Norway. His research interests focuses on using and developing networked business relationships to safeguard customer-valued supply. He applies several institutional approaches including relational contracting theory, the industrial networking approach and transaction cost analyses. He has assisted in establishing this research project and managing the data collection. He has also contributed to analysing and writing up this paper. 